\begin{tabular}{|c|c|c|}
\hline & Int.J.Curr.Microbiol.App.Sci (2021) 10(08): 390-395 & \\
\hline & $\begin{array}{l}\text { International Journal of Current Micro6iology and Applied Sciences } \\
\text { ISSN: 2319-7706 Volume } \mathbf{1 0} \text { Number } \mathbf{0 8} \mathbf{( 2 0 2 1 )} \\
\text { Journal homepage: http://www.ijcmas.com }\end{array}$ & $\begin{array}{l}50 \\
502\end{array}$ \\
\hline $\begin{array}{l}\text { EXCELLENT } \\
\text { PUBLISHERS }\end{array}$ & & whwe.jicmascom \\
\hline
\end{tabular}

\title{
A Comparative Study of Native and Crossbreed Cow Urine Distillate on Carcass Characteristics and Meat Quality of Broilers
}

\author{
A. Sushma ${ }^{1 *}$, P. Eswara Prasad ${ }^{1}$, K. Padmaja ${ }^{1}$ and K. Adilaxmamma ${ }^{2}$ \\ ${ }^{1}$ Department of Veterinary Biochemistry, ${ }^{2}$ Department of Veterinary Pharmacology and \\ Toxicology, College of Veterinary Science, Sri Venkateswara Veterinary University, \\ Tirupati, India \\ *Corresponding author
}

\section{A B S T R A C T}

\section{Keywords}

Cow urine distillate, native breed, crossbreed, broilers, carcass

characteristics, meat quality

Article Info

Accepted:

20 July 2021

Available Online:

10 August 2021
The present investigation was conducted to carry out a comparative study on native and crossbreed cow urine distillate on carcass characteristics and meat quality of broilers. Eighty, day old broiler chicks were randomly assigned into four groups with twenty birds in each group and were acclimatized for four days before the start of cow urine distillate supplementation. Control group T-1 was given drinking water without cow urine distillate, while groups T-2, T-3 and T-4 were provided drinking water mixed with cow urine distillate of Ongole, Sahiwal and Holstein Friesian (H.F) crossbred, respectively @10ml/liter. Six birds from each group were randomly selected and slaughtered on $42^{\text {nd }}$ day for which carcass characteristics and meat quality parameters were recorded. The dressing percentage, heart weight, gizzard weight and various cut up parts viz., wings, thighs, neck, back and breast were not influenced by CUD supplementation. The liver weight was significantly increased in groups T-2 and T-3 compared to T-1 and $\mathrm{T}-4$, whereas percent drumstick yield was significantly higher in group given Ongole CUD (T-2) compared to other groups. However, the meat parameters i.e. meat $\mathrm{pH}$ and ERV showed no significant difference among various groups.

\section{Introduction}

In India, poultry industry is currently one of the fastest growing segments in the National livestock sector owing to its benefits in the form of increased and economic production and for furnishing proteinaceous food (Ganguly and Prasad, 2010). Broiler meat is a vital source of animal protein in human growth and development. Due to its high digestibility, medium-low juiciness, little coarseness, odour and flavor, low-calories, lowest fatty feeling in the mouth and tenderness, broiler meat is in great demand by people all over the world (Ahmed et al., 2017). Nutrition of birds has a significant 
impact on poultry meat quality and safety. The intrinsic characteristics, such as structure, nutrient content, $\mathrm{pH}$, or water availability, have a large impact on spoilage process of meat. Generally, changes in the physicochemical properties of poultry meat might lead to differences in the microbial spoilage process (Albrecht et al., 2019).

Cow is equated to mother in the Indian tradition and her urine panacea of all diseases. Cow urine contains all the substances, which are naturally present in the human body. Thus, consumption of cow urine maintains the balance of these substances and this helps cure incurable diseases. It is natural, eco-friendly with no residual effects, economically and easily available, hence can be harnessed as potential therapeutic agent (Mohanty et al., 2014)

\section{Materials and Methods}

\section{Birds, Diet and Treatment}

Eighty broiler chicks were obtained from a commercial hatchery on day of hatch. Chicks were randomly allocated to four treatment groups with twenty birds per each group. Control group or group T-1, received drinking water without cow urine distillate, while groups T-2, T-3 and T-4 were supplemented drinking water mixed with cow urine distillate of Ongole, Sahiwal and H.F crossbred, respectively. The chicks were reared under deep litter system and were maintained under standard management conditions throughout the experimental period of 42 days. The experimental diet was provided according to the standards prescribed by Bureau of Indian Standards (B.I.S).

\section{Carcass characteristics}

At the end of experiment, six birds from each group were randomly selected and slaughtered. The birds were kept off feed for $12 \mathrm{hrs}$ before the slaughter, but were provided with ad libitum drinking water during that starvation period. Prior to slaughter, each bird was weighed individually. Birds were sacrificed by decapitation using a sterile sharp knife. The skin and feathers were completely removed along with both the legs from knuckle to hock joint. The carcass with the viscera was weighed. Again the carcass was weighed after evisceration. Weight of edible organs and various cut up parts were recorded.

Dressing percentage was calculated by using following formula:

$$
\begin{aligned}
& \text { Dressing \% } \\
& \text { dressed carcass weight }(\mathrm{g}) \\
& \text { =-----×100 } \\
& \text { Pre slaughtered body weight }(\mathrm{g})
\end{aligned}
$$

\section{Meat quality}

Meat $\mathrm{pH}$ was measured by the method of Trout et al., (1992), where 5grams of sample was homogenized with $45 \mathrm{ml}$ of distilled water for about one minute and then $\mathrm{pH}$ was recorded by immersing the combined glass electrode of digital $\mathrm{pH}$ meter in the homogenate.

Extract release volume (ERV) was estimated according to the method of Hilsheimer and Hauschild (1985). 25 grams of minced meat was homogenized with $100 \mathrm{ml}$ of $0.1 \mathrm{M}$ phosphate buffer ( $\mathrm{pH}$ 5.8) and the slurry was filtered through Whatman filter paper for 15 min in a measuring cylinder.

\section{Statistical analysis}

All the data have been presented as mean \pm SE. Statistical comparisons were made using one way analysis of variance (ANOVA) by using computer software SPSS (Version 20). Significant differences $(\mathrm{p}<0.05)$ between 
different experimental groups were analyzed by Duncan's test.

\section{Results and Discussion}

\section{Carcass characteristics}

Results on different carcass parameters were presented in Table 1, $2 \& 3$. The pre-slaughter live weight of the experimental groups T-2 and T-3 were significantly higher by $18.8 \%$ and $13.2 \%$ respectively, when compared to control (T-1) whereas T-4 was higher by $3.2 \%$. However, no significant difference was found in dressing percentages among the treatment groups. The weight of heart and gizzard showed no significant difference in the experimental groups, whereas weight of liver in T-2 and T-3 was significantly higher compared to T-1 and T-4. Parsaie et al., (2007) stated that the liver is a site of detoxification and nutrient metabolism, thus it is dependent on the amount of work it does. Increased size of liver in the present study may be explained by higher nutrient availability for hepatocytes (Zaefarian et al., 2019).

The mean values of various cut up parts viz. wing, thigh, back, neck and breast showed no significant difference between different groups. Significantly increased percentage in drumstick cut was observed in group T-2 compared to other groups indicative of more lean meat with lesser fat content. The differences in the carcass weights of broiler chickens may originate from differences in feed intake and feed conversion ratio (Aluwong et al., 2013).

Mathivanan et al., (2006) reported that carcass characteristics, cut up parts of carcass did not differ due to dietary supplementation of Panchagavya. Patel and Sharma (2013) stated that cow urine ark alone did not show any significant effect on carcass yield of broilers. Pelicano et al., (2004) also reported that cutup parts yield was not significantly affected by inclusion of probiotics.

\section{Meat parameters}

The data obtained from measuring meat parameters was presented in Table $4 \& 5$.

\section{pH}

$\mathrm{pH}$ is one of the most important physicochemical properties of meat and influences other quality characteristics such as emulsifying capacity, emulsion stability, cooking loss, flavor, juiciness, texture and drip loss. Changes in $\mathrm{pH}$ affect both water holding capacity and emulsifying ability of meat. The $\mathrm{pH}$ of meat and meat products is an important measure to estimate relative acidity or alkalinity which might indicate the potential storage life of meat products.

Table.1 Mean values of pre- slaughter live weight and dressing percentage of experimental groups

\begin{tabular}{|c|c|c|}
\hline \multirow{2}{*}{ Treatment groups } & \multicolumn{2}{|c|}{ Mean \pm SE (n=6) } \\
\cline { 2 - 3 } & $\begin{array}{c}\text { Pre- slaughter live weight } \\
(\mathbf{g m})\end{array}$ & $\begin{array}{c}\text { Dressing percentage } \\
(\mathbf{\%})\end{array}$ \\
\hline T-1 & $1865.00^{\mathrm{a}} \pm 49.45$ & $65.50^{\mathrm{a}} \pm 1.77$ \\
\hline T-2 & $2216.67^{\mathrm{b}} \pm 31.27$ & $67.34^{\mathrm{a}} \pm 0.92$ \\
\hline T-3 & $2111.67^{\mathrm{b}} \pm 45.05$ & $69.05^{\mathrm{a}} \pm 1.75$ \\
\hline T-4 & $1925.00^{\mathrm{a}} \pm 61.20$ & $66.24^{\mathrm{a}} \pm 1.72$ \\
\hline
\end{tabular}

Means with different superscripts in each column differ significantly $(\mathrm{p}<0.05)$ 
Table.2 Mean values of heart, liver and gizzard of experimental groups

\begin{tabular}{|c|c|c|c|}
\hline \multirow{2}{*}{ Treatment } & \multicolumn{3}{|c|}{ Mean \pm SE $(\mathbf{n = 6})$} \\
\cline { 2 - 4 } & Heart $(\mathbf{g m})$ & Liver $(\mathbf{g m})$ & Gizzard $(\mathbf{g m})$ \\
\hline T-1 & $9.22^{\mathrm{a}} \pm 0.54$ & $36.29^{\mathrm{a}} \pm 1.16$ & $74.10^{\mathrm{a}} \pm 4.66$ \\
\hline T-2 & $10.34^{\mathrm{a}} \pm 0.33$ & $44.47^{\mathrm{b}} \pm 1.16$ & $76.48^{\mathrm{a}} \pm 3.60$ \\
\hline T-3 & $9.70^{\mathrm{a}} \pm 0.71$ & $46.67^{\mathrm{b}} \pm 1.19$ & $77.64^{\mathrm{a}} \pm 4.54$ \\
\hline T-4 & $10.18^{\mathrm{a}} \pm 0.37$ & $36.91^{\mathrm{a}} \pm 2.69$ & $69.07^{\mathrm{a}} \pm 6.40$ \\
\hline
\end{tabular}

Means with different superscripts in each column differ significantly $(\mathrm{p}<0.05)$

Table.3 Mean values of various cut up parts of experimental groups

\begin{tabular}{|c|c|c|c|c|c|c|}
\hline \multirow{2}{*}{ Treatment } & \multicolumn{6}{|c|}{ Mean \pm SE $(n=6)$} \\
\hline & Wing\% & Thigh\% & Drumstick\% & Neck\% & Back\% & Breast \% \\
\hline T-1 & $7.70^{\mathrm{a}} \pm 0.32$ & $15.94^{\mathrm{a}} \pm 0.25$ & $12.80^{\mathrm{a}} \pm 0.18$ & $4.26^{\mathrm{a}} \pm 0.21$ & $20.20^{\mathrm{a}} \pm 0.16$ & $35.84^{\mathrm{a}} \pm 0.83$ \\
\hline T-2 & $7.70^{\mathrm{a}} \pm 0.23$ & $16.04^{\mathrm{a}} \pm 0.52$ & $13.64^{b} \pm 0.38$ & $4.12^{\mathrm{a}} \pm 0.27$ & $20.87^{\mathrm{a}} \pm 0.76$ & $36.06^{\mathrm{a}} \pm 0.35$ \\
\hline T-3 & $7.55^{\mathrm{a}} \pm 0.19$ & $16.38^{\mathrm{a}} \pm 0.69$ & $12.37^{\mathrm{a}} \pm 0.14$ & $4.12^{\mathrm{a}} \pm 0.29$ & $20.96^{\mathrm{a}} \pm 0.62$ & $36.99^{\mathrm{a}} \pm 0.82$ \\
\hline T-4 & $7.52^{\mathrm{a}} \pm 0.47$ & $15.93^{\mathrm{a}} \pm 0.21$ & $12.15^{\mathrm{a}} \pm 0.08$ & $3.63^{\mathrm{a}} \pm 0.20$ & $20.15^{\mathrm{a}} \pm 0.15$ & $37.04^{\mathrm{a}} \pm 0.79$ \\
\hline
\end{tabular}

Means with different superscripts in each column differ significantly $(\mathrm{p}<0.05)$

Table.4 Mean values of meat $\mathrm{pH}$ and ERV of experimental groups

\begin{tabular}{|c|c|c|}
\hline \multirow{2}{*}{ Treatment groups } & \multicolumn{2}{|c|}{ Mean \pm SE $(\mathbf{n}=\mathbf{6})$} \\
\cline { 2 - 3 } & Meat $\mathbf{p H}$ & $\mathbf{E R V}(\mathbf{m l})$ \\
\hline T-1 & $5.49^{\mathrm{a}} \pm 0.07$ & $17.17^{\mathrm{a}} \pm 1.40$ \\
\hline T-2 & $5.55^{\mathrm{a}} \pm 0.11$ & $20.00^{\mathrm{a}} \pm 1.84$ \\
\hline T-3 & $5.58^{\mathrm{a}} \pm 0.13$ & $17.67^{\mathrm{a}} \pm 1.31$ \\
\hline T-4 & $5.56^{\mathrm{a}} \pm 0.15$ & $19.17^{\mathrm{a}} \pm 0.75$ \\
\hline
\end{tabular}

Means with different superscripts in each column differ significantly $(\mathrm{p}<0.05)$ 
Generally, muscle $\mathrm{pH}$ values are reduced during the immediate post-mortem period; the rate of $\mathrm{pH}$ decline has usually remarkable effects on meat quality. In the present study, the $\mathrm{pH}$ values were not influenced by dietary CUD supplementation. The values obtained in the present study were comparable with Savell et al., (2005) who reported that post rigor meat normally has a $\mathrm{pH}$ of $5.7-5.8$.

\section{Extract release volume (ERV)}

Extract release volume is of value in determining spoilage of meat as well as in predicting shelf life of meat. In this method meat of good microbial and good organoleptic qualities releases large volume of extract while meat of poor quality releases smaller volume.

The mean values of ERV of different treatment groups ranged from 17.17 to 20.00 $\mathrm{ml}$ and they did not differ significantly between different groups. Almost similar values were recorded by Sinhamahapatra et al., (2004) with mean values of $17.75 \mathrm{ml}$ in fresh chicken meat.

Data on slaughter and meat parameters indicated that meat quality is not affected by supplementation of Cow urine distillate in broilers. Further studies on optimum dosage of CUD, on large number of birds are warranted to confirm the beneficial effects.

\section{References}

Ahmed, S. T., Ko, S. Y., and Yang, C. J. (2017). Improving the nutritional quality and shelf life of broiler meat by feeding diets supplemented with fermented pomegranate (Punica granatum L.) by-products. British Poultry Science, 58(6):694-703.

Albrecht, A., Hebel, M., Heinemann, C., Herbert, U., Miskel, D., Saremi, B., and Kreyenschmidt, J. (2019). Assesment of meat quality and shelf life from broilers fed with different sources and concentrations of methionine. Journal of Food Quality, 1: $1-10$.

Aluwong, T., Kawu, M., Raji, M., Dzenda, T., Govwang, F., Sinkalu, V., and Ayo, J. (2013). Effect of yeast probiotic on growth, antioxidant enzyme activities and malondialdehyde concentration of broiler chickens. Antioxidants, 2(4): 326-339.

Ganguly, S., and Prasad, A. (2010). Role of plant extracts and cow urine distillate as immunomodulator in comparison to levamisole-A Review. Journal of Immunology and Immunopathology, 12(2): 91-94.

Hilsheimer, R., and Hauschild, A. H. W. (1985). A modified method for ascertaining water activities within defined limits. Journal of Food Protection, 48(4): 325-326.

Mathivanan, R., Edwin, S. C., Amutha, R., and Viswanathan, K. (2006). Panchagavya and Andrographis paniculata as alternatives to antibiotic growth promoter on broiler production and carcass characteristics. International Journal of Poultry Science, 5(12): 1144-1150.

Mohanty, I., Senapati, M. R., Jena, D., Palai, S. (2014). Diversified uses of cow urine. International Journal of Pharmacy and Pharmaceutical Sciences, 6(3): 20-22.

Parsaie, S., Shariatmadari, F., Zamiri, M. J., and Khajeh, K. (2007). Influence of wheat-based diets supplemented with xylanase, bile acid and antibiotics on performance, digestive tract measurements and gut morphology of broilers compared with a maize-based diet. British Poultry Science, 48(5): 594-600. 
Patel, A., and Sharma, R. K. (2013). Effect of feeding cow urine ark and aloe vera on performance and carcass traits of broilers. Journal of Animal Research, 3(2): 125-129.

Pelicano, E. R. L., De Souza, P. A., De Souza, H. B. A., Leonel, F. R., Zeola, N. M. B. L., and Boiago, M. M. (2004). Productive traits of broiler chickens fed diets containing different growth promoters. Brazilian Journal of Poultry Science, 6(3): 177-182.

Savell, J. W., Mueller, S. L., and Baird, B. E. (2005). The chilling of carcasses. Meat Science, 70(3): 449-459.

Sinhamahapatra, M., Biswas, S., Das, A. K., and Bhattacharyya, D. (2004). Comparative study of different surface decontaminants on chicken quality. British Poultry Science, 45(5): 624630.

Trout, E. S., Hunt, M. C., Johnson, D. E., Claus, J. R., Kastner, C. L., Kropf, D. H., and Stroda, S. (1992). Chemical, physical, and sensory characterization of ground beef containing 5 to 30 percent fat. Journal of Food Science, 57(1): 25-29.

Zaefarian, F., Abdollahi, M. R., Cowieson, A., and Ravindran, V. (2019). Avian liver: the forgotten organ. Animals, 9(2): 6385 .

\section{How to cite this article:}

Sushma, A., P. Eswara Prasad, K. Padmaja and Adilaxmamma, K. 2021. A Comparative Study of Native and Crossbreed Cow Urine Distillate on Carcass Characteristics and Meat Quality of Broilers. Int.J.Curr.Microbiol.App.Sci. 10(08): 390-395.

doi: https://doi.org/10.20546/ijcmas.2021.1008.045 